\title{
The near future of head louse control
}

\author{
Saç biti kontrolünün yakın geleceği \\ *Kosta Mumcuoğlu \\ *Department of Microbiology and Molecular Genetics, The Hebrew University School of Medicine \\ Corresponding author: Dr. Kosta Mumcuoğlu, Parasitology Unit, Department of Microbiology and \\ Molecular Genetics, The Kuvin Center for the Study of Infectious and Tropical Diseases, The Hebrew \\ University Hadassah School of Medicine, 12272, Jerusalem 91120, Israel \\ E-mail: kostasm@ekmd.huji.ac.il \\ Received/ Accepted: December 02, 2014/March 03, 2014 \\ Conflict of interest: The authors stated that they did not have conflict of interests.
}

\begin{abstract}
SUMMARY
Infestation with head lice is a worldwide public health concern. In high income countries pediculosis capitis is a problem mainly in school-aged children. In the last two decades and mainly as a result of resistance to pediculicides with a neurotoxic mode of action and due to the toxicological concerns, a new trend to products acting by physical means such as dimethicone, has been observed. It was shown that these substances are capable of entering the tracheal system and asphyxiating the lice and their eggs. Due to this quality it could be expected that lice, if at all, could not easily develop resistance. Dimethicone is a cosmetically acceptable product, physiologically inert and non-toxic and therefore it is expected to become the treatment-of-choice for lice in the near future.
\end{abstract}

Keywords: Head louse, Pediculus humanus capitis, control, dimethicone, louse comb

\section{ÖZET}

Saç biti enfestasyonu tüm dünyada yaygın bir halk sağlığı sorunudur. Yüksek gelirli ülkelerde pedikülozis kapitis temel olarak okul çağındaki çocuklarda problemdir. Son 20 yılda özellikle nörotoksik yolla etkili pedikülositlere direnç gelișimi ve toksikolojik endișeler nedeniyle, dimetikon gibi fiziksel olarak etkili yeni ürünlere eğilim görülmeye başlanmıştır. Bu maddelerin trakeal sisteme girerek bitleri ve yumurtalarını boğduğu gösterilmiştir. Bu niteliğine bağlı olarak bitlerin en azından kolaylıkla direnç geliştiremeyeceği beklenmektedir. Dimetikon kozmetik açıdan kabul edilebilir, fizyolojik olarak etkisiz ve toksik olmayan bir üründür. Bu nedenle yakın gelecekte bitlerin tedavisinde seçenek olması beklenmektedir.

Anahtar sözcükler: Saç biti, Pedikülus humanus kapitis, kontrol, dimetikon, bit tarağ1

Infestation with the human head louse (Pediculus humanus capitis) occurs worldwide and is an important public health concern. Pediculosis capitis is hyperendemic in many resource-poor populations in the developing world, while in high income countries, head lice are a problem mainly in school-aged children ${ }^{1}$. Despite the use of powerful insecticides and prodigious efforts of parents and health providers, successful control of head louse infestations in most countries remains unattainable. Sale of ineffective pediculicides, incorrect use of pediculicides, use of alternative remedies and methods whose efficacy has not been proven clinically, development of re- sistance to insecticides, improper attention to possible fomite transmission, difficulty in diagnosing head lice infestations and embarrassment and social stigma that prevents reporting, are the main reasons for an ineffective control of head lice. Synergized pyrethrins, pyrethroids such as permethrin, sumithrin, bio-allethrin and d-phenothrin, as well as lindane, malathion, carbaryl and ivermectin are used in the battle against head lice. Toxicological concerns and resistance of lice to different pediculicides, make the use of these chemicals problematic. In the last 20 years, as a result of extensive use, resistance to pediculicides with a neurotoxic mode of action has increased in many industrialized countries, 
particularly to permethrin and other pyrethroids as well as to malathion ${ }^{1-4}$. Therefore, there is a strong trend to switch from neurotoxic insecticides to products acting by physical means. Recently, physically acting preparations based on polydimethysiloxane, known as dimeticone or dimethicone, became the treatmentofchoice in a number of developed countries.

The first dimethicone-based product was Hedrin (in a $4 \%$ lotion formulation). The formulation, with cyclomethicone, as the volatile fluid, was approved as a class I medical device in the UK in 2005. Today, sprays, gels, and lotion formulations of dimethicone are produced in different countries, with exposure times lasting between $15 \mathrm{~min}$ and $8 \mathrm{hrs}$. In most of these formulations a second treatment after 7-10 days is necessary. Some of them are also fully ovicidal so a single treatment would be enough to eliminate the head louse population on the head of an infected individual. A large number of clinical trials were conducted and showed that most of them are highly effective and do not cause any significant side effects ${ }^{5-10}$.

Silicone-based products cause immediate immobilization effect on lice. Earlier invitro studies showed that the fluids were capable of entering the tracheal system, of lice subsequently asphyxiating the lice ${ }^{11}$. More recent studies showed that dimethicone is deposited in the insect's spiracular and tracheal systems, producing a barrier that inhibits excretion of water, which results in osmotic stress leading ultimately to gut rupture in fed insects ${ }^{5}$. Due to these qualities it could be expected that lice, if at all, could not easily develop resistance against these kind of products. Dimethicone is a clear, odorless fluid and cosmetically acceptable product. When applied to the hair, it is not absorbed transdermally but quickly dries out by the evaporation of its solvent, cyclomethicone. Silicones are difficult to wash off, lice remain immobile until death, and treated eggs do not hatch. Dimethicone based products are also used in cosmetic products, e.g., they make the hair silky and soft and facilitate the use of a lice comb. In addition, oral dimethicone is used as an anti-flatulent to alleviate gastrointestinal discomfort. Dimethicone is physiologically inert and non-toxic, and after oral ingestion, the oil is not absorbed but eliminated unaltered in the feces. Topical use in humans is considered safe. In the animal model, no adverse events were observed after topical use of concentrations between $6 \%$ and $79 \%$.

Other agents with a physical action on lice have been evaluated, each in one randomized trial including 1, 2-octanediol, applied in an alcoholic solution, seemed to eradicate lice effectively with no notable adverse effects. Isopropyl myristate is a noninsecticide-based drug commonly used in cosmetics. Not long ago it was introduced in Canada and Europe as a pediculicide. Its mode of action is a mechanical process that weakens the waxy shell of lice, resulting in internal fluid loss and dehydration.

Two of the most widespread products worldwide, i.e., Hedrin and NYDA are sold also in Turkey. In a randomized controlled clinical trial conducted in this country with the former pediculicide, a high cure rate was observed ${ }^{12}$.

It should not be forgotten that the use of a louse comb should be an integral part of any anti-louse control strategy. A finetoothed louse comb can be used: A. for the diagnosis of louse infestation; $b$. for the prevention of louse infestation by suppressing the establishment of lice on the scalp after the initial infestation; c. as an accessory tool for every anti-louse treatment method; $d$. for the treatment of a long term head louse infestation; e. for verification that treatment with a pediculicide was successful; and f. for the removal of nits.

In conclusion; due to advantages of the silicon based products, they will become the treatment-of-choice for individuals suffering from pediculosis capitis in the near future.

\section{REFERENCES}

1. Mumcuoglu KY, Barker SC, Burgess IF. International guidelines for effective control of head louse infestations. J. Drugs Dermatol 2007; 6: 409-14.

2. Mumcuoglu KY. Control of head louse (Anoplura: Pediculidae) infestations: Past and present. Amer. 
Entomol 1996; 42: 175-8.

3. Mumcuoglu KY. Effective treatment of head louse with pediculicides. J. Drugs Dermatol 2006; 5: 451-2.

4. Hemingway J, Miller J, Mumcuoglu KY. Pyrethroid resistance mechanisms in the head louse Pediculus humanus capitis from Israel: Implications for control. Med. Vet. Entomol 1999; 13: 89-96.

5. Burgess IF. The mode of action of dimeticone 4\% lotion against head lice, Pediculus capitis. BMC Pharmacology 2009; 9: 3.

6. Burgess IF, Brown CM, Lee PN. Treatment of head louse infestation with 4\% dimeticone lotion: Randomised controlled equivalence trial. BMJ 2005; 330; 1423.

7. Burgess IF, Lee PN, Matlock G. Randomised, controlled, assessor blind trial comparing $4 \%$ dimeticone lotion with $0.5 \%$ malathion liquid for head louse infestation. PLoS 2007; 2: 1127.

8. Burgess IF, Brunton ER, Burgess NA. Single application of $4 \%$ dimeticone liquid gel versus two applications of $1 \%$ permethrin crème rinse for treatment of head louse infestation: A randomised controlled trial. BMC Dermatology 2013; $13: 5$.

9. Heukelbach J, Pilger D, Oliveira FA, Khakban A. Ariza L, Feldmeier H. Efficacious pediculicide based on dimeticone: Randomized observer blinded comparative trial. BMC Infectious Diseases 2008; 8: 115.

10. Heukelbach J. Asenov A, Liesenfeld $\mathrm{O}$, Mirmohammadsadegh A, Oliveira FA. A new two phase dimeticone pediculicide shows high efficacy in a comparative bioassay. BMC Dermatology 2009; 9: 12.

11. Richling I, Böckeler W. Lethal effects of treatment with a special dimeticone formula on head lice and house crickets Insights into physical mechanisms. Arzneimittelforschung 2008; 58: 248-254.

12. Kurt O, Balcioğlu IC, Burgess IF, Limoncu ME, Girginkardeşler N,
Tabak T, Muslu H, Ermiş O, Sahin MT, Bilac C, Kavur H, Ozbel Y. Treatment of head lice with dimeticone 4\% lotion: Comparison of two formulations in a randomised controlled trial in rural Turkey. BMC Public Health 2009; 9: 441. 